\title{
Aspect and child language acquisition: a Danish perspective
}

\author{
SIGNE JENSEN \\ Handelshøjskolen, Århus, Danmark
}

\begin{abstract}
I følgende bidrag forelægger jeg resultaterne af mit eget studium af danske børns tidlige indlæring af nutid og datid. Jeg viser, hvordan danske børn, i deres tidlige indlæring af disse grammatiske former, synes styret af den såkaldte POA hypotese. Det vil sige, at børnene som udgangspunkt generaliserer brugen af nutidsformen til at beskrive ateliske situationer, mens datidsformen og perfektum bliver brugt primært til at udtrykke teliske situationer.
\end{abstract}

\section{INTRODUCTION}

Within the field of first language acquisition of aspect and tense the primary focus has been on three areas: 1) how young children use past and present tense markers. 2) How children in languages with aspect markers utilize these, and 3) how children comment on certain situations, such as durative as opposed to non-durative situations.

The findings have, with a few exceptions, pointed uniformly in one direction; to a greater or lesser degree, they all bear evidence to what is known as the Primacy of Aspect hypothesis (POA).

The POA predicts that children will restrict their early use of tense and aspect markers to a limited class of verbs according to the inherent lexical aspect of these. It has been found that initially the use of the present tense and the progressive aspect marker is restricted to verbs that name non-resultative and durative events "while past or perfective markers are associated with verbs that name punctual resultative events" (Ping Li and Shirai: 2000, 5) ${ }^{1}$. In other words, it seems that the past tense and the perfective marker are reserved for marking 
telic events whereas the present tense and the progressive aspect, for languages that employ such a device, are employed to express primarily atelic events.

Only a small number of languages have been examined, among these are English, Russian, German, Italian, French, Greek, Hebrew, Chinese (Mandarin), Japanese $^{2}$ and Danish ${ }^{3}$. The POA has been empirically supported, with certain modifications, not only in L1 acquisition but also in L2 acquisition for both classroom as well as naturalistic learners. Moreover, it has been found to apply also to deaf speakers and to Alzheimer patients (Andersen and Shirai: 1996, 547).

\section{ASPECT AND ACQUISITION STUDIES}

In tense and aspect acquisition research, it is customary to encode children's utterances either according to the inherent lexical aspect of the verb in the utterance, more or less in isolation, or according to aktionsarten ${ }^{4}$. The studies that code according to aktionsarten take into consideration the whole proposition and, where possible, its context. The latter approach is in particular employed in experimental studies where, of course, the experimenter is able to control the exact nature of the aktionsarten that s/he wishes to test. Harner (1981: 500), for example, tested children's understanding of goal-oriented as opposed to non-goal-oriented actions in the past and future tense, with examples like, (1) A mouse goes through a tunnel to get some cheese at the other end as opposed to (2) A rocking horse rocked back and forth.

In my coding, I regarded the propositions in their entirety and coded according to aktionsarten because I find it vital to recognize that verbs may change their inherent lexical aspect in their interplay with the linguistic elements in the rest of the proposition. Thus, an example like (4) Han kører ('he's driving') was coded as an activity whereas (5) Han kører ind i tunellen ('he's driving into the tunnel') was coded as an accomplishment due to the result-like nature of the act, i.e. being in the tunnel as the ultimate goal of the action.

The question, which is unfortunately much too extensive for the present context to answer, is, of course, whether children have an awareness of verb semantics (inherent lexical aspect), or whether they employ an idealized conceptualization of situations (aktionsart) when they use the present and past tense. 


\section{THE DANISH STUDY}

\subsection{The data}

My data is derived from two Danish longitudinal case studies ${ }^{5}$. I made use of two separate corpora: one consisting of 54 recording sessions with a boy starting at the age of 1.00.26 and ending at the age of 6.01.02., the other consisting of 42 recordings with a girl starting at the age of 1.01.01 and ending at the age of 2.11.11.

For each child, I recorded every instance of past, present and perfect use. For each verb use, I recorded the age of the child, the tense of the verb and the aktionsart.

I performed calculations on the data according to two parameters: 1) for each tense I calculated the percentage of use with each class of verbs/situations. 2) For each class of verbs/situations I calculated the percentage of occurrences with a given tense.

\subsection{The findings}

The primary and most obvious observation to make in connection with the data is that there is a tremendous amount of present tense uses and unfortunately only a few simple past tense and perfect form uses. This, of course, leaves any observation made in connection with past and perfect use open to scrutiny. In the analysis of present tense use, however, general tendencies can be established with much greater certainty.

On the whole, the children's present tense marking seems to follow the stipulations of the POA. Initially, they overwhelmingly use the present tense marker as a tool to express activities and states. Gradually, however, throughout the recordings, they use the present tense marker less and less to express atelic constructions. In other words, the present tense marker, as is to be expected, becomes less and less associated with atelic aktionsarten only and acquires a more differentiated use.

Interestingly, from the outset the past forms are used much more with telic aktionsarten than the present tense is, and these forms become increasingly 
employed with telic aktionsarten. The perfect form in particular seems to be strongly associated with telicity.

Surprisingly, the perfect form seems to be associated also with states. This is interesting given the very different qualities inherent in states (continuity and openness) as opposed to achievements and accomplishments (clear definable boundaries). However, Jacobsen (1986), as cited by Shirai and Andersen (1996), also found in her study of Spanish children that they used, in their case, the past participle to express "[...] entry into states that continue into the present" (1996: 537). In the present study, it is not an entry into states, though, which the states coupled with the perfect form express, but rather, in actual fact, results of processes. Looking closely at the states that the children couple with the perfect form, there is a general tendency for these to indicate states that have come about due to a process or an action in the past. These states thus come to express observable results of these past processes or actions rather than merely refer to timeless states such as e.g. to want, to know, to think, etc.

To illustrate, the girl says: (6) Den er lukket ('It is closed'), (7) Den er i stykker ('It is broken'), (8) Den er vendt om ('It is turned inside out'), (9) Det er broekket ('It is broken'), (10) Er låst op ('It is unlocked'), (11) Er gået af ('It has come off') and (12) Har siddet sådan huse ('Has been sitting like that house'). All of these examples point out visible results of past processes: in (6), the object is locked as a result of someone locking it, in (7) someone has broken the object and the result is that is broken, in (8), she has put her jacket on inside out and thus it is now inside out, in (9), someone has broken an object causing the object to be broken into pieces, in (10) the object referred to is unlocked due to someone unlocking it, and in (11) something has lost its attachment to another object due either to a process (someone deliberately trying to detach the objects) or due to a punctual action (maybe it just fell off). Finally, in (12), a house (toy) is missing from the place where it used to be, presumably because someone has removed it.

The perfect form's meaning that 'something which has happened prior has present relevance' fits well the semantics of these utterances: a process in the past has present relevance because it has resulted in a state. This use is similar to 
Italian children's use of the past participle described by Antinucci and Miller (1976):

\begin{abstract}
[...] the children are focusing on the result of the event described by the verb [...] the children treat the past participle as an adjective: it describes a state of the object ([...] it agrees with the noun with which it is in construction). As a result of the change denoted by a transitive verb, the object comes to be in a state; for example the action described by somebody broke the toy results in the state the toy is broken. The children are using the past participle to describe the END-STATE of the process or action (1976: 172-173).
\end{abstract}

The perfect form, if we accept this analysis, is reserved almost exclusively for telic aktionsarten. Even if we discard this analysis, the result remains the same; the perfect form is reserved for telic aktionsarten. This is so because, if we choose to re-categorize the perfect uses as adjectival uses, these verb-uses are instead counted as copula-uses and as a consequence the percentage distribution in the perfect form changes. The great number of states disappears causing the percentage of achievements and accomplishments expressed by the perfect form to increase.

The number of states is rather substantial in the simple past as well. However, this form does not seem to be reserved for expressing telicness as the perfect form is. Thus, the relatively high number of states expressed by the simple past is probably merely a reflection of its more varied function.

The preliminary conclusion can be drawn that, to a certain extent, Danish children are also driven by the principles of the POA at least until the age of 3; 0 . They use the present tense to express atelic aktionsarten and the perfect form, and to a certain degree the past tense, to express telic aktionsarten. However, after the age of $2 ; 6$ there seem to be a development, although subtle, away from the POA in terms of present tense marking. The past forms, on the other hand, seem increasingly to adhere to the POA.

However, all types of aktionsarten (parameter II, see p. 3) are most strongly associated with the present tense. The different aktionsarten only begin to be used more evenly with the forms around the age of $2 ; 6$. It is also at this age that the tendencies for the past tense and the perfect form to be associated with telic 
aktionsarten are most audible. The present tense is, at this age, clearly becoming less associated with telic aktionsarten whereas the other two forms are acquiring this association.

\title{
3.3. The present tense and atelic aktionsarten
}

By the time the present tense seems to acquire a more differentiated use, the past forms seem to progressively follow the POA. These seemingly contrasting tendencies probably reflect the fact that the present tense is the first tense to be acquired. Consequently, it is possible that by the time the past tense and the perfect form have been acquired and have gained a natural, rather than sporadic, place in the children's language, the children have become so familiar with using the present tense that they are able to extend its uses. Thus, the present tense is loosing its association with atelic aktionsarten slowly but surely; whereas, in parallel, the association between pastness and telicness is only just beginning to be established.

However, throughout these early recordings there are a great number of both states and activities in general compared to achievements and accomplishments. It is unlikely that it simply reflects a preference on part of the children to talk about states and activities as opposed to accomplishments and achievements. In fact Stoll (1998) claims to the contrary that:

\begin{abstract}
[o]ne can assume that it is far more interesting and worth reporting an event in isolation, i.e. without narrative elaboration, if there is a qualitative change of state, e.g. the breaking of a window, or a result, e.g. when reading completely through a book, than if there is only a temporal change of state, e.g., the inception of an activity like playing (1998: 374).
\end{abstract}

The reason for the relatively low occurrence of telic aktionsarten is to be found, I believe, in the greater degree of complexity connected to these. Toivonen (1997) argues, in connection with Swedish children's acquisition of intransitive and transitive body - posture verbs that:

[w] hen learning intransitive body-posture verbs, the child only has to concentrate on which position the object is in, whereas learning the transitive in addition involves distinguishing between the mover and the moved object, and also knowing which participant's posture that must be taken into account (1997: 37). 
This line of argument can readily be extended to the present discussion. In connection with states and activities, the child only has to concentrate on (1) the agent/doer and (2) the activity/state, e.g. (13) in I'm playing or (14) I'm sitting, there are only two points of concern: the agent and the activity (playing) or state (sitting). In connection with achievements and accomplishments, however, the child needs to concentrate, in the most complex cases, on: (1) the agent, (2) the affected object or subject, (3) the action being carried out, (4) the goal of the action and (5) the patient/recipient. In, for example (15), I'm driving the car over to mummy, there is (I) an agent, (2) an affected object (the car), (3) the action (driving) and (4) the final destination (by the mother), who is also (5), the recipient.

It is, of course, only natural that the more complex aktionsarten are more difficult for the children to express. Bowerman (1989) states that "[t]he relative difficulty of meaning plays an important role in the time of acquisition of linguistic forms" (1989: 137). Toivonen (1997) argues that her subjects even at the age of $5 ; 1$ had a much better command and understanding of the intransitive utterances than the transitive utterances (1997: 38). Thus, it also seems plausible that children have a much better command of expressing states and activities than of accomplishments and achievements.

I performed a token count on the girl's data to see whether she merely used the same types of states and activities repeatedly, and consequently did not in actual fact master these aktionsarten more adequately than she mastered accomplishments and achievements.

However, overall, the girl did seem to use a greater variety of states and activities than of accomplishments and achievements. Furthermore, she used some of the state and activity types more than she used any of the achievement and accomplishment types.

Thus, it seems that telic aktionsarten are more difficult for children to learn. This could explain children's fondness for coupling activities and states with the present tense from the outset; activities and states are relatively simple situations, and the present tense is quite naturally the first form to be learned. 
Increasingly with age, activities and states are described more often both by the past forms and by the present tense.

\section{CONCLUSION}

In the present article I have discussed Danish children's use of the present and past tense forms.

Danish children, in their early use of the present and past forms, behave similar to children of other linguistic backgrounds in that they follow the principles of the POA, which state that the present tense, in early child language, is employed to express primarily states and activities [-telic] whereas the past tense and the perfect form, on the other hand, are used primarily to express achievements and accomplishments [+telic].

Initially, most aktionsarten are associated with the present tense. However, around the age of $2 ; 6$, telic aktionsarten increasingly become more associated with the simple past and the perfect form. At this age the simple past and the perfect form are increasingly established in the children's language. It is thus only at this age that we are able to witness the workings of the POA in connection with the simple past tense and the perfect form.

The present tense is thus moving away from the POA whereas the past and perfect forms only seem to begin to adhere to this. It is my conjecture that this might be due to the fact that the present tense is acquired first. Thus, at the age when the past and perfect are only beginning to establish a pattern of use with telic aktionsarten, the present is slowly becoming disassociated with atelic aktionsarten.

It is an interesting fact that an overwhelming amount of aktionsarten in the data is atelic. This, I speculate, may be due to the relatively lesser degree of complexity inherent in atelic aktionsarten.

An activity, or state, only has two important points of focus: the agent and the activity carried out by the agent, or the state s/he is in. Telic aktionsarten, on the other hand, have as much as 5 points of focus: the agent, the patient/recipient, the action, the affected and goal of the action. Thus, it is hardly surprising that children prefer (are better able) to talk about activities and states. 
The above argument offers an alternative explanation to the POA, as to why the present tense is used so much with these aktionsarten, i.e. it is simply because they are less complex to use.

However, it is interesting and in support of the POA that children in their earliest use prefer to express telic aktionsarten with the past forms. Furthermore, even when the children start to use more telic aktionsarten, the present tense is still associated with activities and states whereas the past and perfect form are more associated with telic aktionsarten.

In terms of the simple past, this form, even though it is used more with telic aktionsarten than the present is, is not the prime form for expressing telic aktionsarten. The simple past is used both with telic as well as atelic aktionsarten, and increasingly so.

The perfect form, in actual fact, is the primary tool for expressing telic aktionsarten. There is an interesting tendency initially, however, for the perfect form to also be associated with states. These states, though, express resultant states of previous processes. In, for example, Den er ødelagt ('It is broken'), presumably the object in question has been broken by someone. Thus, the state of being broken is the result of the process of breaking rather than being an inherent timeless state. Hence, the perfect form's willingness - even preference to express these states is nicely in tune with the POA.

It is vital, however, and would be interesting, to carry out a more comprehensive study of Danish children's early use of the past and present tenses in order to be able to draw more definite conclusions.

\section{REFERENCES}

Andersen, Roger William, Yasuhiro Shirai (1996), "Primacy of aspect in first and second language acquisition: the pidgin-creole connection", in: Ritchie, W., K. Bhatia Tej (eds.) (1996), Handbook of second language acquisition, San Diego: Academic Press, Inc., pp. 527-562.

Antinucci, Francesco, Ruth Miller (1976), "How children talk about what happened", Journal of child language, 3, (1976), pp. 167-189.

Bache, Carl (1985), Verbal aspect. A general theory and its application to present-day English, Odense: Odense University Press. 
Behrens, Heike (2001), “Cognitive-conceptual development and the acquisition of grammatical morphemes: the development of time concepts and verb tense", in: Bowerman, M., S. C. Levinson (eds.) (2001), Language acquisition and conceptual development, Cambridge: Cambridge University Press, pp. 450475.

Berman, Ruth née Aronson, Dan Isak Slobin (1994), Relating events in narrative: $a$ cross-linguistic developmental study, New Jersey: Lawrence Erlbaum Publishers.

Bickerton, Derek (1999), "Creole languages, the language bio program hypothesis and language acquisition", in: Ritchie, W. C., Tej K. Bhatia (eds.), Handbook of child language acquisition, San Diego: Academic Press, Inc., pp. $195-220$

Bloom, Lois, Karin Lifter, Jeremie Hafiz (1980), "Semantics of verbs and the development of verb inflections in child language", in: Language, 65, (1980), pp. 386-412.

Bowerman, Melissa (1989), "Learning a semantic system: what role does cognitive predisposition play?", in: Rice, M., R. L. Schiefelbusch (eds.) (1989), The teachability of language, Baltimore, MA: Paul Brookes Publishing Company, pp. 133-171.

Bronckart, Jean Paul, Hermina Sinclair (1973), "Time, tense and aspect", in: Cognition, 2, (1973), pp. 107-130.

Cziko, Gary, Keiko Koda (1987), “A Japanese child's use of stative and punctual verbs", in: Journal of child language, 14, (1987), pp. 99-111.

Frawley, William (1992), Linguistic semantics, New Jersey: Lawrence Erlbaum Publishers.

Harner, Lorraine (1981), "Children talk about the time and aspect of actions", Child development, vol. 52, no. 1, (1981), pp. 498-506.

Jensen, Signe (2001), The fundamental process character of the English progressive, Odense, unpublished.

Jensen, Signe (2002), The acquisition of tense and aspect in early child language: an examination of the POA hypothesis from a Danish perspective, Odense, unpublished.

Ping, Li, Yasuhiro Shirai (2000), The acquisition of lexical and grammatical aspect, Berlin: Mouton De Grutyer.

Shirai, Yasuhiro, Roger William Andersen (1995), "The acquisition of tenseaspect morphology: a prototype account", in: Language, 71, (1995), pp. 743762.

Smith, Carlotta (1997), The Parameters of aspect, Dordrecht: Kluwer Academic Publishers.

Stoll, Sabine (1998), "The role of aktionsart in the acquisition of Russian aspect", in: First Language, 18, (1998), pp. 351-377.

Toivonen, Ida (1997), The acquisition of body-posture verbs in Swedish (Personal copy), Stanford University, unpublished dissertation.

Vendler, Zeno (1967), "Verbs and times", in: Vendler, Zeno (1987), Linguistics in philosophy, Ithaca, New York: Cornell University Press, pp. 97-122. 


\section{NOTES}

1 Henceforth the terms 'telic' and 'atelic' aktionsart will be employed to refer to resultative and non-resultative aktionsarten respectively.

2 See e.g.: (English) Andersen, Shirai (1996), Bloom, Lifter, Hafiz (1980), (Russian) Stoll (1998), (German) Behrens (2001), (Italian) Antinucci, Miller (1976), (French) Bronckart, Sinclair (1973), (Chinese) Shirai, Andersen (1995) and (Japanese) Cziko, Koda (1987).

3 This study was originally carried out as part of my masters thesis at The University of Southern Denmark Odense, titled: The acquisition of tense and aspect in early child language: an examination of the POA hypothesis from a Danish perspective (2002).

4 Most studies, including the present study, code according to Vendler's (1967) classic four-way classification of either verbs or aktionsarten: accomplishments, achievements, states and activities.

5 I am indebted to Kim Plunkett for kindly allowing me to use his recordings. 